\title{
Raw Material Resources for Extruding
}

\section{Tatiana Marinchenko}

Rosinforagroyekh, Pravdinsky, Moscow region, Russian Federation

ORCID:

Tatiana Marinchenko: http://orcid.org/0000-0003-3721-112X

\section{Abstract}

Substantial research has been devoted to the problems of more rational feeding of animals, improving the quality and nutritional value of existing feeds with a general reduction in the cost of their production, as well as the search for new and alternative sources of feed and methods for their preparation. At the same time, the scientific community is faced with issues of finding the best ways to recycle agricultural and food production waste. Since agricultural producers and processors also face the problem of recycling a variety of waste, the practical implementation of research in these areas is one of the main tasks of the agricultural sector. This article examines the feasibility of organizing on-farm production of animal feed based on a mobile extruder plant that

Corresponding Author: Tatiana Marinchenko 9419428@mail.ru

Published: 5 April 2021

Publishing services provided by Knowledge E

(c) Tatiana Marinchenko. This article is distributed under the terms of the Attribution License, which permits unrestricted use and redistribution provided that the original author and source are credited.

Selection and Peer-review under the responsibility of the DonAgro Conference Committee.

\section{G OPEN ACCESS} uses waste from the production and processing of crops, food and other industries. This would reduce feed costs, increase the efficiency of using internal feed resources and would utilize production waste. This approach would significantly reduce the cost of livestock products or could become a source of additional income. The data on the extrusion of a number of non-traditional sources of feed products, such as waste from leather production, grape processing, mushroom cultivation, etc., are provided.

Keywords: agriculture, animal husbandry, feeding, alternative feed resources, production waste, extruding, efficiency

\section{Introduction}

The issue of feed supply is fundamental for livestock, poultry, and fisheries and determines the efficiency of production and its competitiveness. The grain content in traditional compound feed recipes is quite high and reaches from 60 to $80 \%$. The global livestock sector has a steady tendency to reduce the cost of grain for feed purposes. In many countries, grain in the composition of animal feed accounts for 12 to $15 \%$; fodder products prepared from agricultural waste, grain processing and food and other industries, the so-called secondary raw materials (SRM), occupy a significant share here.

The dependence of domestic livestock breeders on grain makes the economy of livestock production dependent on a number of hard-to-predicted factors, such as yield, prevailing market conditions, domestic feed stocks and financial security of farms. 
The problem of finding new sources of feed and methods for obtaining feed, improving their quality while reducing production costs is especially urgent today and is one of the main tasks of the agricultural sector in the Russian Federation [1, 2].

Solutions are being sought all over the world and it should be noted that issues of wider use of non-traditional sources and crop waste are discussed in the scientific community around the world.

It should be noted that issues of a wider use of non-traditional sources and waste of crop production are discussed in the scientific community around the world. C. Devendra and C.C. Sevilla noted in their work that with a sufficiently large potential, there is a problem of insufficient involvement in the feeding of animals of unconventional feed and plant residues [3].

René Renato Balandrán-Quintana et al. note in their paper that agro-industrial wastes are economic sources of proteins that need to be involved, for which it is necessary to improve traditional extraction methods [4].

M. Gonzalez-Valadez et al. note that the use of extruder treatment of plant residues and low-cost industrial by-products in animal feed is a good alternative for farmers in developing countries, especially in the dry season due to lack of feed [5].

At the same time, there is the problem of accumulation and disposal of large amounts of little used or generally unused industrial wastes and substandard raw materials. These are SRM, which after having been processed promptly can acquire a number of new being initially absent useful qualities and properties, as well as a nutritional value, which exceeds 1.5 to 3 times the nutritional value of feed grain having a good quality. The amount of production of raw materials, which are hardly used, but potentially suitable for feed purposes, is many times greater than the amount of specially produced feed components. Their quantity, which can be obtained from unused waste, may exceed the local feed requirement in the regional aspect.

\section{Methods and Equipment}

The material for the study was foreign and domestic authors' scientific publications on the problems of improving the quality of existing feed products for finding new sources of feed, as well as methods for feed preparation, as well as recycling of production waste and data on Russian projects in this area. Methods used were monographic ones, the comparative and system analysis, idealization and mental modeling, as well as a logical approach 


\section{Results}

Emphasizing the potential of agricultural waste, Christianah O. Jayeola et al. said, "Today, waste is seen and referred to as raw material for the production of various products, and is well regarded for its economic value. Technology has substantially improved the physical and nutritional value of many waste products. Rather than exporting their wastes for meager foreign exchange earnings, many countries are developing technological capabilities to convert more of their wastes into useful products" [6].

The total amount of agricultural waste in the Russian Federation reaches 630 to 650 million metric tons. Lumber and woodworking waste amounts to 700 million metric tons, food and food processing industry waste averages 30 million metric tons per year. The largest part of the waste falls on the livestock industry (56\%), the second place is taken by crop waste (35.6\%). The processing industries account for $4.7 \%$ of waste (Fig. 1) [7].

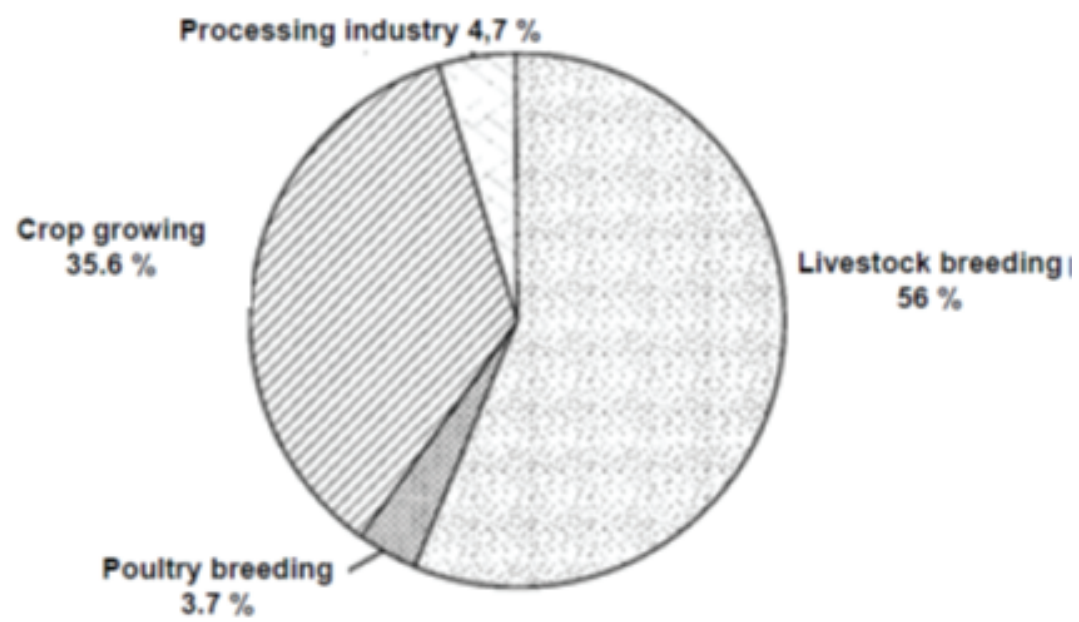

Figure 1: Structure of waste generation in agriculture of the Russian Federation.

For example, the plant-growing branches of the agricultural sector generate annually 150,000 metric tons of straw; 3,000 metric tons of husks of rice, millet, buckwheat, and sunflower; 1,000 metric tons of corn cobs; 100,000 metric tons of flax shive; 350,000 metric tons of sorghum waste (juice, stem mass). About 40 million metric tons of SRM and production waste are generated annually in the food industry sectors of the agribusiness. Ninety three per cent of the total amount of the generated waste or about 32 million metric tons of generated secondary raw materials are involved in the economic turnover. However, far from all and not everywhere, SRM and food processing industry wastes are involved in processing [8]. Crop wastes account for about half of the gross production of straw, tops of agricultural plants, etc., and only half of the straw and not more than $30 \%$ of the tops are used for livestock feed. The rest of the straw 
and tops are practically not used, they are burned or decayed in the fields and in places of temporary storage.

It is extremely inefficient to use straw, grain waste and screenings of the milling industry, bran, corn stalks and any other crop waste, as well as vegetable waste from the wine, beer and confectionery industries. Moreover, the amount of plant waste is several times higher than the share of the target grown products. An example is the often-applied direct application of plant waste (chopped straw, tops, etc.) to the ground as organic fertilizer, which leads to the fact that nitrogen in the soil, so necessary for plants, is used not to feed the root system, but in the decomposition of organic residues. It is known that extrusion increases from 2 to 2.5 times the digestibility and nutritional value of straw due to the destruction of lignin as the inhibitor of digestibility and due to lignin denaturation into sugar, which in turn reduces the need to introduce molasses into the diet [7].

Potentially possible revenues from the sale of products obtained from these sources can significantly exceed the revenues from the sale of the main product and increase the overall profitability of production by at least 300-400 \% [1].

One of the universal methods of preparing fodder raw materials for feeding animal and poultry, as well as processing biological waste, is the extrusion method, it allows using SRM for feed purposes with almost no restrictions. Experts have repeatedly noted high nutritional value of such processed products that can acquire a number of new being initially absent useful qualities and properties, as well as a nutritional value, which exceeds 1.5 to 3 times the nutritional value of feed grain having a good quality $[9,10]$.

M. Gonzalez-Valadez et al. also note that the use of extrusion of plant residues and low-cost industrial by-products in animal feed is a good alternative for farmers, especially in the dry season due to lack of feed [11].

The equipment developed by Bioenergy \& K LLC for the production of animal feed and feed additives based on extrusion make it possible to involve in processing almost all little used or unused SRM. Studies have shown that extrusion can apply to plant residues and waste from grain processing, canning, confectionery, dairy, winemaking, starch, tea, essential oil, oil and fat, sugar, alcohol, brewing and leather industries. Thus, the stocks of raw materials for feed production according to this extruder processing technology are not limited.

Along with the involvement of conditioned plant and biological components, the technology allows restoring and repeatedly increasing the feed nutritional value of raw materials infected with pathogenic microflora, spoiled by insects or partially decomposed due to violation of the rules and storage conditions. Extruding substandard 
components destroys pathogenic microflora, helminth eggs, pathogens of serious diseases (brucellosis, tuberculosis, cholera, typhoid, etc.), as well as pathogenic parasitic protozoa and helminths (roundworm, tapeworms, etc.). At the same time, the feed value of substandard raw materials after such processing exceeds 1.1 to 1.4 times the feed value of standard analogues, since extrusion increases the digestibility of nutrients, makes them more accessible to the digestive systems of animals, poultry and fish, and reduces enzyme and energy body expenditure for digestion and assimilation of the latter.

Studies have shown that the products obtained after extrusion comply with accepted standards for nutrition and the content of the required set of vitamins and minerals, are veterinary safe, can be certified, are environmentally friendly, and the technology itself solves the problem of recycling industrial waste and can solve issues of improving the environmental aspects of production. The average cost of producing one kilogram of such feed is commensurate with the cost of one kilogram of feed grain, while the feed value is 1.4-2.0 times higher than that of the feed grain.

There are many promising sources for extrusion processing and involvement in feed production. Extruding, for example, leather wastes, makes it possible to obtain a cheap fodder product with a protein corresponding to fishmeal of the first grade, with good technological properties, such as flowability, long shelf life, pleasant smell and 450 times lower bacteriological contamination than that allowed by Russian state standards for fish and meat and bone meal.

The Russian Federation imports thousands of metric tons of fishmeal from Argentina, Peru, the Mauritanian Islands and other countries to fill the protein shortage. According to FWRC FPA (former All-Russian Williams Fodder Research Institute) (analytical report by A.S. Shpakov, V.G. Ryabov, Yu.K. Novoselov and V.V. Rudoman) Russia produces less than 330,000 metric tons of fish and meat and bone meal with a total demand of more than 920,000 metric tons. At the same time, tanneries in Russia monthly export leather cuttings and shreds in an amount of about 100 metric tons per month for recovery.

The production of such a feed product is highly profitable. Leather cuttings at the tanneries of Russia are sold to the population as heat insulation and filler for non-food purposes at a price of 30 kopecks to 1 ruble per $1 \mathrm{~kg}$, the cost of processing is 4-5 rubles per $\mathrm{kg}$. Due to the fact that this feed product is notable for its low cost and high protein content, there is a real opportunity to use it as a substitute for fish meal, which is one of the most expensive components of animal feed; it is only required to balance the difference in the content of methionine, cystine, tryptophan and some other components. Taking into account the introduction of these components into the feed 
product, the cost will be 1 to 2 rubles, considering which the total cost of the product will be 7 to 8 rubles. The price of fishmeal is not less than 30 rubles per $\mathrm{kg}$.

Tanneries often dispose of fleshings in a landfill as a production waste, since its removal as biological waste requires considerable expenses. After processing, fleshings turn from waste into profit, namely, into a protein feed supplement for all types of animals.

There is positive experience in the Chelyabinsk region: an enterprise for the production of animal protein from skin wastes has been producing feed suitable for all types of animals for more than 3 years, a similar production is planned to be commissioned in the Nizhny Novgorod region.

Foreign studies on the use of leather wastes in the feeding of farm animals and poultry are also known $[12,13]$.

Other sources include a large number of formed during fishing non-varietal, contaminated with opisthorchiasis, weed river and lake fish, which is a waste for fishing enterprises and often thrown into landfills. The technology allows accommodating the processing plant directly on a barge and producing fishmeal immediately after sorting.

S. Goldhor and J. Regenstein note in their work, "Disposal of fish waste at sea or in landfills is both expensive and highly regulated. Fish processors must, therefore, find new ways to address the problem of waste disposal. With fewer fish being caught, the pressure to maximize profit by using every part of each fish is intense" [14].

In the south of Russia, thousands of metric tons of waste are thrown out during grape processing. At best, they are transported to the fields as fertilizers. Experiments on the extrusion of these wastes showed that after processing, they were superior to feed barley in terms of nutrition and amino acid content.

Until the end of the 80s, almost every farm had an aggregate of vitamin-grass meal. Carotene-containing granules from needles and herbs were prepared for wintering. However, almost everywhere production has now ceased to exist. According to information from the same analytical report (A.S. Shpakov et al.), over 800,000 metric tons of vitamin premixes are consumed annually in Russia. In this case, carotene and vitamins of groups B, C, K and D in the form of wood needles are burned in large quantities. Needles have a unique set of vitamins; a large number of domestic scientific works are devoted to its qualities and properties. Coniferous flour is a vitamin feed. One can get 60 to $100 \mathrm{mg}$ of carotene and 3,000 to 4,000 I.U. per gram of vitamin C from $1 \mathrm{~kg}$ of dry matter of pine needles; this is more than can be found in oranges or lemons [1].

Coniferous flour with a good composition had two drawbacks: bitterness and poor digestibility due to inhibitors, tarry and essential oils, the edibility due to which did not 
exceed 8 to $10 \%$. During extrusion, tarry and essential oils volatilize and the edibility of processed needles reaches $100 \%$ [15].

Based on the performed studies, a process for producing vitamin-carotene flour with low cost and good consumer qualities has been developed using a small installation that can be mounted on any tractor sled, there is no expenditures for fuel and equipment, only electricity is needed. Almost any forestry is able to arrange the release of vitamincarotene flour. It is most rational to launch such production in the winter and spring months, when the needles reach the highest vitamin content, animals are deficient in vitamins in the diet, and farms have free equipment and working hands.

A large amount of waste is produced during the cultivation of oyster mushroom (Pleurotus ostreatus), which is currently established almost everywhere throughout the country. Wastes from the production of such plants are also discarded everywhere, however, after they having been extruded, a highly nutritious feed for polygastric animals is obtained.

Many bean grains have a low digestibility due to the inhibitors contained. For example, peas can be given to poultry maximum 7 to $8 \%$ of the diet, and maximum $5 \%$ - to cows. However, after extrusion, it can be introduced into the diet in an amount of up to $80 \%$.

As for food processing industry waste, it is rich in nutrients, harmless, easier to respond to enzymatic and microbiological bioconversion and various types of pretreatment [16]. These resources are considered as the most promising for the development of alternative feed production technologies.

\section{Discussion}

In accordance with the "Strategy for the Ecological Safety of the Russian Federation for the period until 2025", environmental safety must be ensured through the introduction of innovative and environmentally friendly technologies, and the development of environmentally friendly industries as well. Existing technologies for industrial production of agricultural products lead to inefficient consumption, loss of natural resources and increase in the environmental burden on the environment. Therefore, investments in resource-saving structural adjustment that radically changes the technological basis of production make it possible today to achieve greening, reducing costs for eliminating negative environmental consequences and to gain technological advantages that increase competitiveness in the market.

Extrusion provides feed with high zootechnical and consumer performance. The resulting feed is highly nutritious (protein content is 22 to $24 \%$ ), has easier digestibility, 
biological activity, as well as enzyme, vitamin and mineral value. As for the resource base for extrusion processing, almost all SRM can be considered as promising for the development of alternative feed production technologies.

Studies have shown that the products obtained after extrusion comply with accepted standards for nutrition and the content of the required set of vitamins and minerals, are veterinary safe, can be certified, are environmentally friendly, and the technology itself solves the problem of recycling industrial waste and can solve issues of improving the environmental aspects of production. The average cost of producing $1 \mathrm{~kg}$ of such feed is commensurate with the cost of $1 \mathrm{~kg}$ of feed grain, while the feed value is 1.4 to 2.0 times higher than that of the feed grain.

An important feature of extrusion is its comprehensiveness, which consists in the ability to simultaneously solve the most important problems of agricultural enterprises: firstly, providing farms with high-quality feed while reducing the overall cost of this item, and secondly, solving the environmental issue of the waste management, which is very relevant within resource-saving tasks assigned to countries.

\section{Conclusion}

Switching to the environmentally reasonable and safe management consists in promoting economically accessible and environmentally sound technological and technical solutions, as well as managerial techniques aimed at the introduction of resource-saving and low-waste industries and technological re-equipment of enterprises.

Increasing the pace of economic development in agriculture, food and forestry industries, the recent closer attention to environmental issues, the implementation of switching to the principles of the best available technologies leads to the need to review the use and disposal of associated waste.

Extrusion is an effective method of preparation of feed, because it allows combining mechanical, thermal and chemical influences simultaneously and continuously. Such a combined effect changes the structure of fiber: there is dextrinization of starch to glucose, protein denaturation, inactivation of digestive tract inhibitors, neutralization of toxic substances, sterilization of feed, and improvement of palatability. These qualitative changes increase the feed intake, as well as their digestibility accessibility in the animal's body.

In the course of such processing, humidity is reduced by 30 to $40 \%$; pathogenic microflora, helminth eggs, as well as harmful parasitic protozoa, insects and worms are destroyed in raw materials of substandard quality. This factor plays an important role 
in unfavorable sanitary conditions of feed raw materials. In this aspect, extrusion is an excellent tool for simultaneously solving the most important problems of agricultural enterprises: firstly, providing farms with high-quality feed while reducing the overall cost of this item, and secondly, solving the environmental issue of the waste management, which is very relevant within resource-saving tasks assigned to countries.

\section{Conflict of Interest}

The author has no conflict of interest to declare.

\section{References}

[1] Krasilnikov, O. Y. and Marinchenko, T. E. (2018). The Relevance of Effective Feed Production. Agrarian Bulletin of the South-East, vol. 2, issue 19, pp. 44-46.

[2] Perednya, V. I., Baranovsky, I. V. and Chumakov, V. V. (2015). Extrusion Technologies in Feed Production. Bulletin of the All-Russian Scientific Research Institute of Animal Husbandry Mechanization, vol. 4, issue 20, pp. 60-63.

[3] Devendra, C. and Sevilla, C. C. (2002). Availability and use of Feed Resources in Crop-Animal Systems in Asia. Agricultural Systems, vol. 71, issues 1-2, pp. 59-73.

[4] Balandrán-Quintana, R. R., et al. (2019). Plant-Based Proteins. Proteins: Sustainable Source, Processing and Applications, pp. 97-130.

[5] Gonzalez-Valadez, M., Munoz-Hernandez, G. and Sanchez-Lopez, R. (2008). Design and Evaluation of an Extruder to Convert Crop Residues to Animal Feed. Biosystems Engineering, vol. 100, issue 1, pp. 66-78.

[6] Jayeola, C. O., et al. (2018). Production of Bioactive Compounds From Waste In Grumezescu, A. M., Holban, A. M. (eds) Therapeutic, Probiotic, and Unconventional Foods (London: Elsevier, Academic Press) pp. 317-340, https://doi.org/10.1016/B9780-12-814625-5.00017-0

[7] Fedorenko, V. F., et al. (2017). Deep Processing of Agricultural Raw Materials. Moscow: Rosinformagrotekh.

[8] Antimonov, S. V., et al. (2013). Study of the Process of Grinding Grain Raw Materials Following Shock Freezing. Bread Products, vol. 11, pp. 60-62.

[9] Artemova, E. I., Kochieva, A. K. and Kapustkin, A. V. (2011). Efficiency of the Organization of On-Farm Production of Animal Feed. Multi-Topic Network Electronic Scientific Journal of the Kuban State Agrarian University, vol. 69, pp. 258-269. 
[10] Romali, V. S. and Kartashov, S. G. (2015). Carbohydrate-Protein Feed Based on Plant Materials. Bulletin of the All-Russian Scientific Research Institute of Animal Husbandry Mechanization, vol. 4, issue 20, pp. 15-18.

[11] Gonzalez-Valadez, M., Munoz-Hernandez, G. and Sanchez-Lopez, R. (2008). Design and Evaluation of an Extruder to Convert Crop Residues to Animal Feed. Biosystems Engineering, vol. 100, issue 1, pp. 66-78.

[12] Jiang, T., et al. (1992). Nutrition of Feed Collagen Protein Powder from the Reclamation Treatment of Chrome Leather Scrap. Animal Feed Science and Technology, vol. 37, issues 3-4, pp. 175-184.

[13] El Boushy, A. R., et al. (1991). Tanning Waste By-Product from Cattle Hides, its Suitability as a Feedstuff. Bioresource Technology, vol. 35, issue 3, pp. 321-323.

[14] Waldron, K. (2007). Handbook of Waste Management and Co-Product Recovery in Food Processing (vol. 1). Washington, D.C.: Woodhead Publishing Limited, pp. 388416.

[15] Pakhomov, V. I., et al. (2018). Effectiveness of New Technologies for Compensation of Carotene Deficit in Fodder. Machinery and Equipment for Rural Area, vol. 1, pp. 18-20.

[16] Braginets, S. V., Alferov, A. S. and Bakhchevnikov, O. N. (2016). Technological Module for the Production of Extruded Mixed Feed with Addition of Vegetable Mass. Machinery and Equipment for Rural Area, vol. 4, pp. 26-28. 